\title{
Protective Effect of Adhatoda vascia Nees Against Radiation-Induced Damage at Cellular, Biochemical and Chromosomal Levels in Swiss Albino Mice
}

\author{
Meenal Kumar ${ }^{1}$, Ravindra Samarth ${ }^{1}$, Madhu Kumar ${ }^{1}$, Senthamil R. Selvan ${ }^{2}$, \\ Begraj Saharan ${ }^{1}$ and Ashok Kumar ${ }^{1}$
}

${ }^{1}$ Laboratory of Radiation and Cancer Biology, Department of Zoology, University of Rajasthan, Jaipur 302004, India and ${ }^{2}$ Hoag Comprehensive Cancer Center, Newport Beach, CA 92663, USA

\begin{abstract}
Extract of Adhatoda vasica (L) Nees leaves has been used for treatment of various diseases and disorders in Ayurved and Unani medicine. Modulatory effect of ethanolic extract of A. vasica (L) Nees against radiation-induced changes in terms of histological alterations in testis, reduced glutathione (GSH), lipid peroxidation (LPO), acid and alkaline phosphatases levels, and chromosomal alterations in Swiss albino mice was studied at various post-irradiation intervals between 1 and 30 days. Mice exposed to 8 Gy radiation showed radiation-induced sickness including marked changes in histology of testis and chromosomal aberrations in bone marrow cells with $100 \%$ mortality within 22 days. When ethanolic leaf extract of $A$. vasica was given orally at a dose of $800 \mathrm{mg} \mathrm{kg}^{-1}$ body weight per mouse for 15 consecutive days and then exposed to radiation, death of Adhatoda-pretreated irradiated mice was reduced to $70 \%$ at 30 days. The radiation dose reduction factor was 1.43 . There was significantly lesser degree of damage to testis tissue architecture and various cell populations including spermatogonia, spermatids and Leydig cells. Correspondingly, a significant decrease in the LPO and an increase in the GSH levels were observed in testis and liver of Adhatoda-pretreated irradiated mice. Similarly, a significant decrease in level of acid phosphatase and increase in level of alkaline phosphatase were observed. Adhatoda pretreatment significantly prevented radiation-induced chromosomal damage in bone marrow cells. The study suggests that Adhatoda plant extract has significant radioprotective effects on testis that warrants further mechanistic studies aimed at identifying the role of major ingredients in the extract.
\end{abstract}

Keywords: acid and alkaline phosphatases - gamma radiation - GSH - LPO - testis

\section{Introduction}

The primary objective of this investigation is to develop and evaluate potential radioprotective phytochemicals in the events of radiation exposures and accidents. A survey of literature may show that plant extracts from Ocimum sanctum $(1,2)$, soya (3), Vitis vinifera (grape seed) (4), Adhatoda vasicagle marmelos (5), Spirulina fusiformis (6), Mentha

For reprints and all correspondence: Meenal Kumar, PhD, Department of Pathology and Laboratory Medicine, Cytogenetics Laboratory, University of California at Los Angeles, Los Angeles, CA, USA, 90095. Tel: +1-310-7941287; Fax: +1-310-794-5099; E-mail: meenalkumar@hotmail.com piperita (7), Brassica compestris (8), Amaranthus paniculatus (9), Withania somnifera (10) and Ginsan (11) possess potential radioprotective activity in mammals. We have recently observed that $A$. vasica Nees (Family: Acanthaceae) has restored hematological changes caused by irradiation in Swiss albino mice (12). A vasica, an evergreen gregarious and perennial shrub (Fig. 1), has been used as an herbal remedy for allergen-induced bronchial obstruction $(13,14)$, asthma $(15,16)$, tuberculosis (17-19) and possesses antioxidant and chemopreventive agent. Since it enhances the activities of glutathione $S$-transferase in the liver of mice (20), we have examined the effects of $A$. vasica extracts on the levels of 


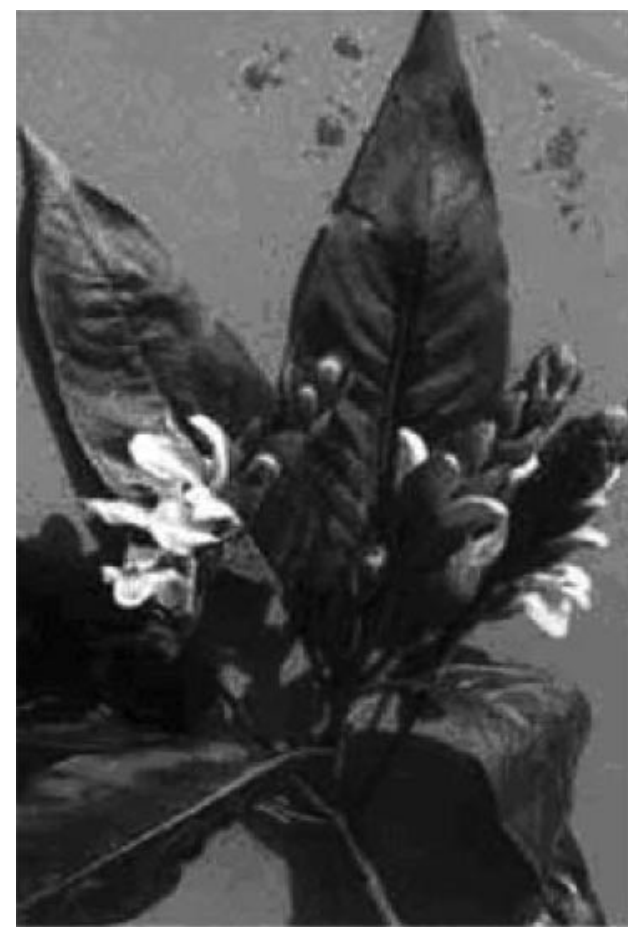

Figure 1. Adhatoda vasica Nees.

reduced glutathione (GSH) in liver, lipid peroxidation (LPO), and acid and alkaline phosphatases in testis of normal and irradiated mice. In addition, we have determined the radioprotective potential of A. vasica in terms of restoration of radiation-induced effects on the tissue architecture and cellularity of testis, and chromosome aberrations in the bone marrow cells.

\section{Methods}

\section{Mice}

Swiss albino male mice (Mus musculus), 6-8 weeks old with body weight of $24 \pm 2 \mathrm{~g}$, were used. Mice were obtained from Hamdard University, New Delhi, India and maintained and bred in mouse house, as an inbred colony as per norms laid down by an Institutional Ethical Committee, given standard mouse food and water ad libitum.

\section{Irradiation}

Mice were irradiated by ${ }^{60} \mathrm{Co}$ source in the cobalt teletherapy unit (ATC-C9) at Radiation Oncology Department, Sawai Man Singh Medical College and Hospital, Jaipur, India. The mice were kept in ventilated box with a distance of $77.5 \mathrm{~cm}$ from the source to deliver a dose-rate of $1.33 \mathrm{~Gy} \mathrm{~min}^{-1}$.

\section{Adhatoda Extract}

Fresh leaves of A. vasica (Fig. 1) were collected from the Herbarium, University of Rajasthan, Jaipur, India and shade-dried. Dried leaves were subjected to three changes of $80 \%$ ethanol at room temperature. The extracts were pooled, lyophilized, weighed and preserved at $4{ }^{\circ} \mathrm{C}$ until use.

\section{Experimental Design}

Mice were randomly divided into following groups (five per group):

Group 1: Normal/sham-irradiated mice were given doubledistilled water (DDW) through oral gavage once in a day for 15 consecutive days.

Group 2: Mice were treated with $800 \mathrm{mg} \mathrm{kg}^{-1}$ body weight of A. vasica dried extract dissolved in distilled water through oral gavage for 15 consecutive days.

Group 3: Mice were given distilled water for 15 days and then exposed to $8 \mathrm{~Gy}$ dose of gamma radiation. This group served as positive control.

Group 4: Extract of A. vasica was given $800 \mathrm{mg} \mathrm{kg}^{-1}$ body weight of mouse orally for 15 days and after $30 \mathrm{~min}$ of last dose; they were exposed to 8 Gy dose of gamma radiation. Following various treatments, mice were autopsied by cervical dislocation on days $1,3,7,14$ and 30. Testis were surgically removed, weighed and fixed in Bouin's fluid. The tissue was embedded in a paraffin block after dehydrating with increasing concentrations of 70,90 and $100 \%$ ethanol. Five micrometer sections were cut using hand microtomy, were placed on glass slide and were stained with Harris hematoxylin and eosin. Stained tissue sections were observed under light microscope (Olympus) to determine histopathological changes.

\section{Survival Assay}

For survival studies mice of both control and experimental groups were exposed to whole body gamma radiation $(6,8$ and $10 \mathrm{~Gy}$ ) and were checked daily for 30 days. The survival percentage of mice up to 30 days of exposure against each radiation dose was used to construct survival dose-response curves. Regression analysis was done to obtain $\mathrm{LD}_{50 / 30}$ values and to determine dose reduction factor (DRF).

\section{Cytogenetics of Bone Marrow Cells}

Mice (all groups) were injected intraperitoneally with $0.025 \%$ colchicine and sacrificed $2 \mathrm{~h}$ later by cervical dislocation. Femurs were dissected out and bone marrow cells were aspirated and washed in physiological saline, treated hypotonically $(0.075 \mathrm{M} \mathrm{KCl})$, and fixed in Carnoy's fixative and stained with $4 \%$ Giemsa. Metaphase slides were prepared by air-drying method of Savage (21). Chromosomal aberrations were scored using oil immersion (with $100 \times$ object lens) under a light microscope.

\section{GSH Assay}

GSH in liver was measured using the method described by Moron et al. (22). Liver homogenates were treated with 
$0.1 \mathrm{ml}$ of $25 \%$ trichloroacetic acid (TCA) and the resulting precipitate was pelleted by centrifugation at $3900 \mathrm{~g}$ for $10 \mathrm{~min}$. Free endogenous sulfhydryl was assayed in a total $3 \mathrm{ml}$

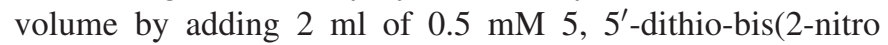
benzoic acid) (DTNB) prepared in $0.2 \mathrm{M}$ phosphate buffer ( $\mathrm{pH} 8$ ) to $1 \mathrm{ml}$ of the supernatant. The GSH reacts with DTNB and forms a yellow-colored complex with DTNB. The absorbance was read at $412 \mathrm{~nm}$ using UV-VIS Systronic spectrophotometer.

\section{LPO Assay}

LPO levels in testis and liver were estimated by the method of Ohkawa et al. (23) as thiobarbituric acid (TBA) reactive substances. The liver and testis were dissected out and chilled in ice cold $0.09 \% \mathrm{NaCl}$. Homogenate of desired tissues were prepared in $1.15 \% \mathrm{KCl}(1 \mathrm{~g}$ tissue in $9 \mathrm{ml}$ of $1.15 \% \mathrm{KCl})$. Sodium dodecyl sulfate $(8.1 \% ; 0.2 \mathrm{ml})$ was added to $0.2 \mathrm{ml}$ of sample in test tubes and $\mathrm{pH}$ was adjusted to 3.5 with $5 \mathrm{M} \mathrm{NaOH}$. To this, $1.5 \mathrm{ml}$ of $0.8 \%$ aqueous solution of TBA was added. The mixture was made up to $4 \mathrm{ml}$ with distilled water and heated at $95^{\circ} \mathrm{C}$ for $60 \mathrm{~min}$. After cooling under tap water, $1 \mathrm{ml}$ of distilled water and $5 \mathrm{ml}$ a mixture of $n$ butanol and pyridine (15:1) were added and shaken vigorously. The solution was centrifuged at $3900 \mathrm{~g}$ for $10 \mathrm{~min}$. The upper organic layer was removed and absorbance was measured at $532 \mathrm{~nm}$ using UV-VIS Systronic spectrophotometer.

\section{Acid and Alkaline Phosphatase Activity}

Acid and alkaline phosphatase activities in testes were estimated using the method described by Fiske and Subbarow (24). The tissue homogenates were mixed with TCA and then centrifuged at $3900 \mathrm{~g}$ for $10 \mathrm{~min}$. The supernatant was then treated with molybdate solution. (Molybdate solution was prepared by dissolving $25 \mathrm{~g}$ of ammonium molybdate into
$200 \mathrm{ml}$ glass distilled water (GDW) and combining with $300 \mathrm{ml}$ of $10 \mathrm{~N} \mathrm{H}_{2} \mathrm{SO}_{4}$ and then was made up to $1000 \mathrm{ml}$ with GDW.) This resulted in the formation of phosphomolybdic acid from the phosphate present in the tissue. The phosphomolybdic acid was then reduced by 1-anilino-8naphthalenesulfonic acid (ANSA) to produce a blue color whose intensity was proportional to the amount of phosphate liberated. The alkaline phosphatase activity is the difference between inorganic phosphate content of the incubated and control samples expressed as Bodansky units. One Bodansky unit corresponds to the liberation of $1 \mathrm{mg}$ of inorganic phosphorous from the tissue in $\mathrm{mg} \mathrm{g}^{-1} \mathrm{~h}^{-1}$ (24).

\section{Statistical Analysis}

Student's $t$-test was employed to analyze the results (25). $P$-values $<0.05$ were considered significant. Regression analysis was done to obtain $\mathrm{LD}_{50 / 30}$ values and to determine DRF.

\section{Results}

\section{Dose Reduction Factor}

Adhatoda leaves (Fig. 1) extract (AE) was given as 100, 200, 400,800 and $1200 \mathrm{mg} \mathrm{kg}^{-1}$ body weight of mouse per day in DDW orally to Swiss albino mice for 15 consecutive days. The extract was non-toxic and no mortality was observed till day 30 . An optimum dose of $800 \mathrm{mg} \mathrm{kg}^{-1}$ body weight of AE was selected against $8 \mathrm{~Gy}$ radiations on the basis of maximum survivability as depicted in Fig. 2. The percent survival was significantly increased in AE-fed mice subsequently treated with irradiation (AE-pretreated irradiated mice). When survival data were fit on regression line equation, $\mathrm{LD}_{50 / 30}$ values for control (irradiated alone) and experimental (AE plus irradiation) were computed as 6.47 and $9.3 \mathrm{~Gy}$, respectively.

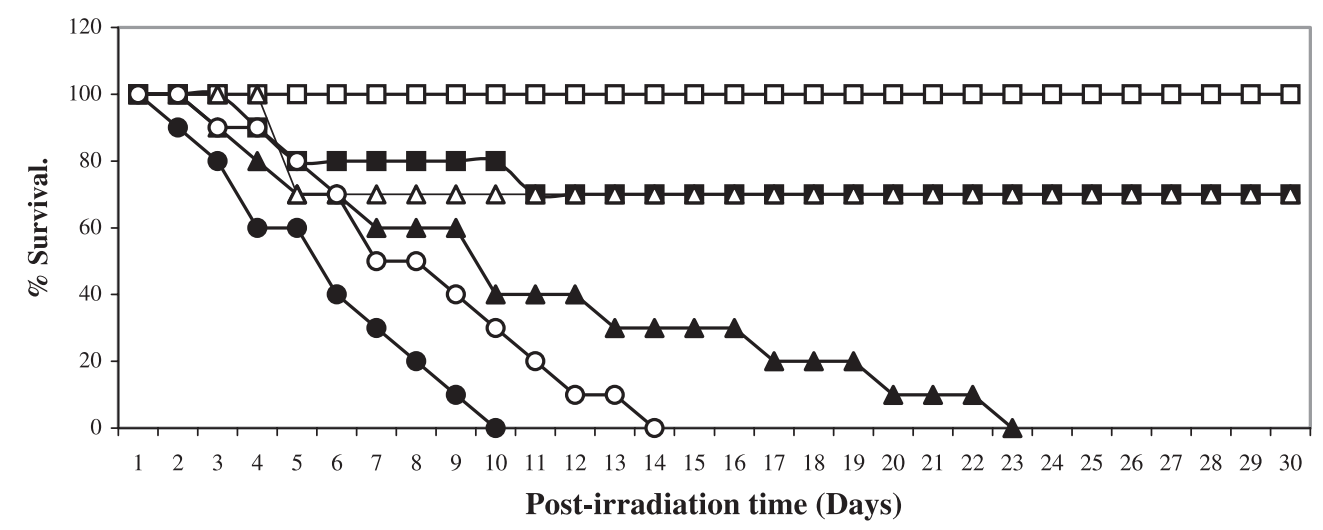

\begin{tabular}{ll|}
$-\longrightarrow$ Control 6Gy & $-\square-$ Experimental 6Gy \\
- Control 8Gy & $-\Delta$ Experimental 8Gy \\
- - Control 10Gy & -0 - Experimental 10 Gy \\
\hline
\end{tabular}

Figure 2. Survival-dose-response curves for determination of $\mathrm{LD}_{50 / 30}$. Control and experimental (Adhatoda-pretreated; $800 \mathrm{mg}$ kg ${ }^{-1}$ body weight) groups were exposed to whole body gamma radiation at 6,8 and $10 \mathrm{~Gy}$ and were checked daily for 30 days. In Adhatoda-pretreated mice, a maximum survival of $70 \%$ was observed at radiation dose rate of $8 \mathrm{~Gy}$. Regression analysis was done to obtain $\mathrm{LD}_{50 / 30}$ values and to determine dose reduction factor (DRF). 
Table 1. Change in body weight and testis weight of male Swiss albino mice in different groups

\begin{tabular}{|c|c|c|c|c|c|}
\hline Experimental groups & Day 1 & Day 3 & Day 7 & Day 14 & Day 30 \\
\hline \multicolumn{6}{|l|}{ Body weight (g) } \\
\hline Normal (DDW) & $21.32 \pm 1.05$ & $22.34 \pm 0.85$ & $24.33 \pm 1.22$ & $24.65 \pm 1.16$ & $26.23 \pm 1.18$ \\
\hline Adhatoda alone (800 $\mathrm{mg} \mathrm{kg}^{-1}$ body weight) & $21.25 \pm 0.22$ & $22.41 \pm 1.20$ & $25.33 \pm 2.14$ & $25.32 \pm 1.00$ & $30.22 \pm 0.70^{* *}$ \\
\hline Radiation (8 Gy) & $20.3 \pm 0.62$ & $18.0 \pm 0.25^{* * *}$ & $17.0 \pm 0.16^{* * *}$ & $16.30 \pm 0.24 * * *$ & No survival \\
\hline Adhatoda + radiation $\left(800 \mathrm{mg} \mathrm{kg}^{-1}\right.$ body weight $\left.+8 \mathrm{~Gy}\right)$ & $21.05 \pm 0.68$ & $20.01 \pm 0.69^{*}$ & $21.00 \pm 1.32 * *$ & $24.50 \pm 1.33 * * *$ & $26.00 \pm 1.80$ \\
\hline \multicolumn{6}{|l|}{ Testis weight (mg) } \\
\hline Normal (DDW) & $74.00 \pm 0.57$ & $75.26 \pm 0.88$ & $76.01 \pm 1.22$ & $75.22 \pm 0.84$ & $76.22 \pm 0.78$ \\
\hline Adhatoda alone ( $800 \mathrm{mg} \mathrm{kg}^{-1}$ body weight) & $75.00 \pm 1.55$ & $74.00 \pm 1.99$ & $77.00 \pm 2.34$ & $77.50 \pm 1.86$ & $82.00 \pm 2.34^{*}$ \\
\hline Radiation (8 Gy) & $71.40 \pm 0.71^{*}$ & $68.60 \pm 1.62 * * *$ & $58.80 \pm 1.33^{* * *}$ & $36.60 \pm 2.87 * * *$ & No survival \\
\hline Adhatoda + radiation $\left(800 \mathrm{mg} \mathrm{kg}^{-1}\right.$ body weight $\left.+8 \mathrm{~Gy}\right)$ & $72.10 \pm 2.05$ & $72.50 \pm 0.80^{*}$ & $63.50 \pm 0.89 * *$ & $60.90 \pm 1.55^{* * *}$ & $68.90 \pm 2.12$ \\
\hline
\end{tabular}

Values are depicted as Mean \pm SD.

Significance level: $* P<0.05 ; * * P<0.01 ; * * * P<0.001$.

Statistical comparison: Adhatoda versus normal (DDW); radiation versus normal (DDW); Adhatoda + radiation versus radiation.

On basis of these $\mathrm{LD}_{50 / 30}$ values, $\mathrm{AE}$ pretreatment produced a DRF of 1.43 .

\section{Inhibition of Radiation-Induced Change in Total Body Weight by $A$. vasica}

As depicted in Table 1, in AE-treated mice, there was no significant change in body weight on days 1, 3, 7 and 14 while a significant increase $(P<0.01)$ was observed on day 30 when compared with mice fed with distilled water alone. Notably, in irradiated mice, the body weight was drastically decreased on day $3,(P<0.001)$, day $7(P<0.001)$ and day $14(P<0.001)$ when compared with mice treated with distilled water only. In AE-pretreated irradiated mice, the body weight significantly increased on day $3(P>0.05)$, day $7(P<0.01)$ and day $14(P<0.001)$ of observation as compared to irradiated group. To note, by day 30 , all mice died in radiation-treated group, but in AE-pretreated irradiated group, $70 \%$ mice survived.

\section{Inhibits Changes in Testis A. vasica}

Mice treated with A. vasica extract alone showed no significant change in weight of the testis on days $1,3,7$ and 14 (Table 1). However, on day 30, a significant weight increase $(P<0.05)$ was observed as compared to mice treated with distilled water. Mice treated with radiation alone ( $8 \mathrm{~Gy}$; Group 3) showed reduction in the testis weight during all days of observation (day 1: $P<0.05$; day 3 : $P<0.001$; day 7 : $P<0.001$ and day 14: $P<0.001)$. Whereas in Adhatodapretreated irradiated group (AE plus radiation), there was a significant increase in testis weight after day $3(P<0.05)$, $7(P<0.01)$ and $14(P<0.001)$ when compared with irradiated mice (Table 1). In irradiated mice, there was a drastic depletion of spermatogonial population with necrotic and pyknotic nuclei were observed (Fig. 3B) when compared with mice treated with distilled water (Fig. 3A). The germinal epithelium was highly disorganized with shrinkage of tubules and cytoplasmic vacuolization (Fig. 3C). Total absence of sperm and spermatids were observed. Sertoli cells and Leydig cells showed shrinkage in their size (Fig. 3D). While in mice pretreated with $\mathrm{AE}$, less damage to spermatogonial population and germinal epithelium was observed with more rapid recovery (Fig. 3E). In irradiated mice, there was significant decrease in number of spermatogonia type $A$ and type $B$ was noticed on all days of observation (Fig. 3B-D). Similar decrease was also found in the number of primary spermatocyte, secondary spermatocyte and spermatid. Notably, in mice pretreated with $\mathrm{AE}$ and then exposed to radiation dose, the quality (as determined by intact germinal epithelium, no pyknosis, necrosis, karyolysis present, less cytoplasmic vacuolization) and number of germ cells increased by day 30 , the histology of testis revealed near normal histoarchitecture except some cytoplasmic vacuolization and lumen with full of sperms (Fig. 3G).

\section{Reduction of Radiation-Induced Chromosomal Aberrations by A. vasica}

The exposure to radiation caused severe cytogenetic damages in bone marrow cells (Fig. 4B) when compared with mice treated with distilled water (Fig. 4A). Various types of aberration like chromatid breaks, chromosome breaks, fragments, and rings, chromosome exchange, and dicentric characteristics were observed in irradiated group (Fig. 4B). In contrast, in AE-pretreated irradiated mice, a significantly lesser degree of these aberrations were observed (Fig. 4C).

\section{Inhibition of GSH Levels in Liver by A. vasica}

Glutathione level in liver was found to significantly increase at autopsy intervals of day $7(P<0.05)$, day $14(0.001)$ and day $30(P<0.001)$ in Adhatoda-treated mice when compared 

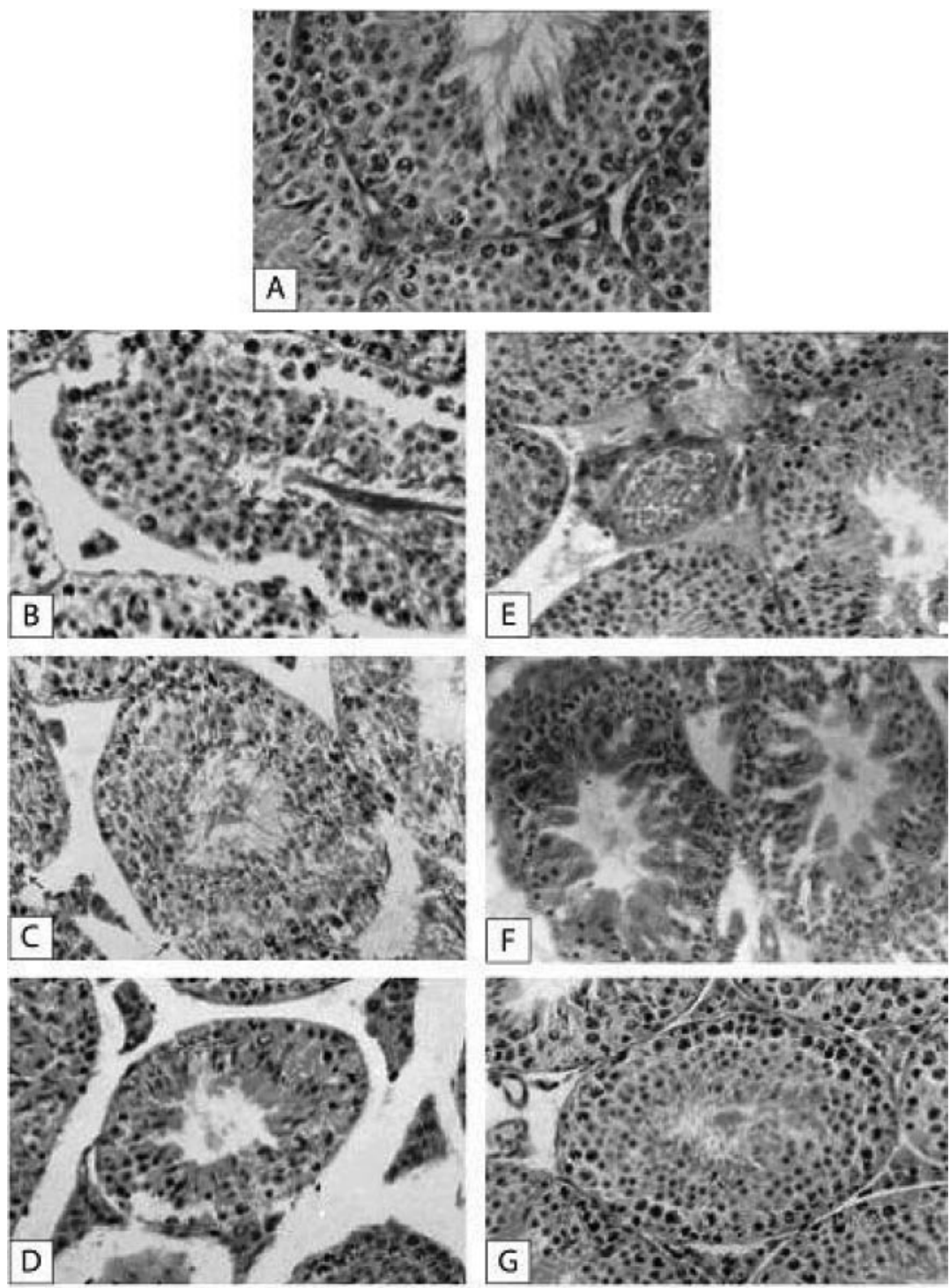

Figure 3. Modulation of radiation-induced histological changes in testis of mice by A. vasica extract. (A) Normal testis showing compact and organized arrangement of spermatogenic cells, spermatogonia types A and B, primary spermatocytes, secondary spermatocytes, spermatids, Sertoli cells and Leydig cells. (B) Exposure to irradiation at day 1: distortion of germinal epithelium and depletion of spermatogonia were evident. (C) Shrinkage of tubule with broken germinal epithelium at day 3 of radiation exposure was seen. (D) More shrinkage of tubules at day 7. Cytoplasmic vacuolization was observed. (E) In Adhatoda-pretreated irradiated mice, at day 1, less damage with increased spermatogonial population was observed. (F) In Adhatoda-pretreated irradiated mice at day 3 , increase in germ cell population and less cytoplasmic vacuolization was observed. (G) In Adhatoda-pretreated irradiated mice at day 30, there was an increase in tubular diameter with reduced interstitium and testis had its normal structure.

with mice treated with distilled water (Table 2). In irradiated group, the GSH content showed significant decrease at all autopsy intervals. Notably, as shown in Table 2, in AEpretreated irradiated mice, a significant increase in GSH content was observed at all intervals when compared with irradiated mice.

\section{Inhibition of upregulation of LPO Levels in Liver and Testis by $A$. vasica}

In Adhatoda extract (AE)-treated mice, a significant decrease in LPO level in liver was noticed on day $14(P<0.01)$ and day $30(P<0.05)$ as compared to those treated with distilled water (Table 3). In irradiated group, LPO level was increased $(P<0.001)$ at all autopsy intervals of observation in terms of thiobarbituric acid reactive substances (TBARS). On the other hand, in AE-pretreated irradiated mice, a significant inhibition in LPO level was observed (Table 3).

The LPO level in testis of $A$. vasica-treated mice was significantly $(P<0.05)$ decreased on day 14 and day 30 as compared to those treated with distilled water (Table 4). In irradiated group, a noticeable elevation of LPO was observed at all intervals from day 1 to day 14. In AE plus radiation experiment group, a significant $(P<0.001)$ reduction in LPO level was seen from day 3 onwards as compared to irradiated group (Table 4). 

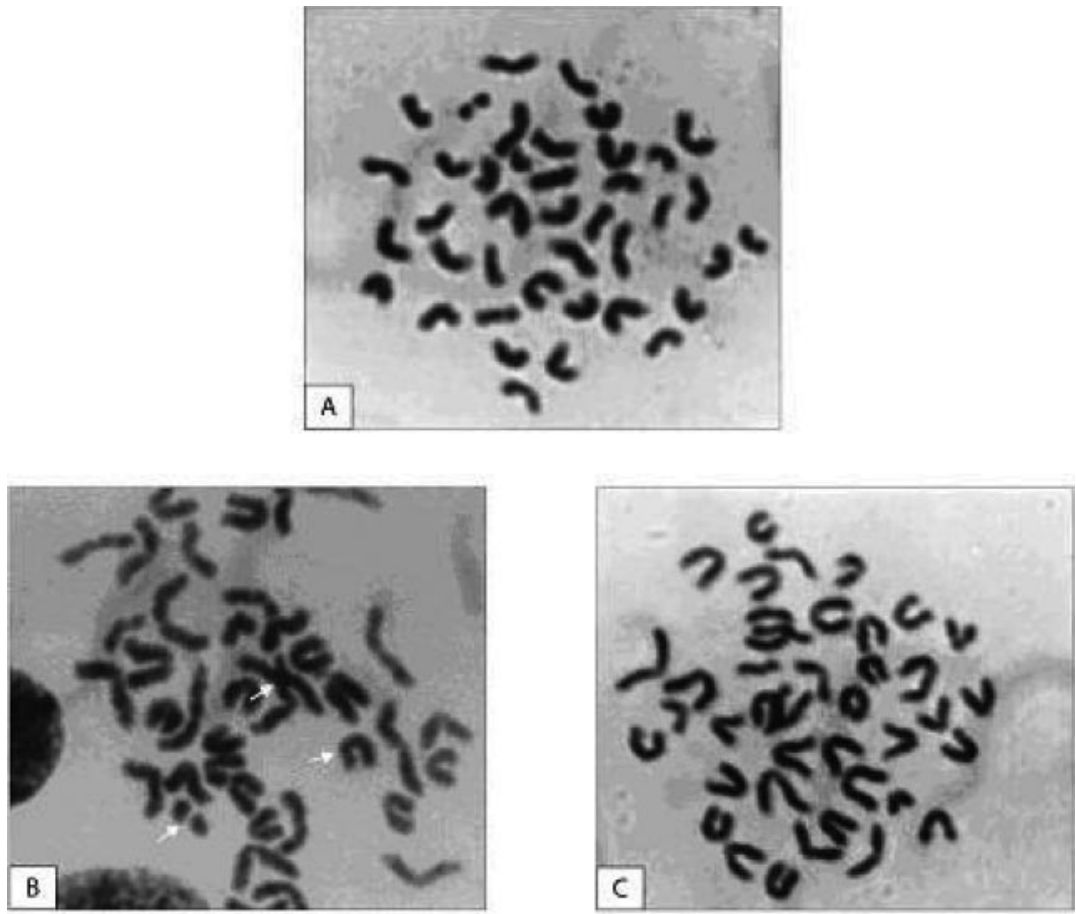

Figure 4. Modulation of radiation-induced chromosomal aberrations in bone marrow cells of mice by A. vasica extract. (A) Normal metaphase showing 40 chromosomes in mice treated with distilled water. (B) Irradiation-induced chromatid breaks, exchange and translocation (white arrows). (C) Adhatodapretreated irradiated mice with representative near normal chromosomes.

Table 2. Reduced glutathione (GSH) levels ( $\mu \mathrm{mol} \mathrm{g}^{-1}$ of tissue) wet weight in the liver of Swiss albino mice in different groups

\begin{tabular}{|c|c|c|c|c|c|}
\hline \multirow[t]{2}{*}{ Experimental groups } & \multicolumn{5}{|c|}{ Autopsy intervals (in days) } \\
\hline & Day 1 & Day 3 & Day 7 & Day 14 & Day 30 \\
\hline Adhatoda alone ( $800 \mathrm{mg} \mathrm{kg}^{-1}$ body weight) & $94.26 \pm 1.45$ & $95.20 \pm 1.37$ & $97.28 \pm 1.68 *$ & $102.68 \pm 1.94 * * *$ & $103.66 \pm 1.85^{* * *}$ \\
\hline Radiation (8 Gy) & $50.25 \pm 2.17 * * *$ & $42.12 \pm 1.56^{* * *}$ & $40.38 \pm 1.56^{* * *}$ & $45.10 \pm 1.50 * * *$ & No survival \\
\hline $\begin{array}{l}\text { Adhatoda }+ \text { radiation } \\
\left(800 \mathrm{mg} \mathrm{kg}^{-1} \text { body weight }+8 \mathrm{~Gy}\right)\end{array}$ & $54.25 \pm 1.54 *$ & $55.02 \pm 1.55^{* * *}$ & $62.60 \pm 2.40 * * *$ & $66.40 \pm 1.65^{* * *}$ & $80.82 \pm 2.68$ \\
\hline
\end{tabular}

Values are depicted as Mean $\pm \mathrm{SD}$.

Normal (DDW): $93.20 \pm 1.62$.

Significance level: $* P<0.05 ; * * P<0.01 ; * * * P<0.001$.

Statistical comparison: Adhatoda versus normal (DDW); radiation versus normal (DDW); Adhatoda + radiation versus radiation.

Table 3. Change in lipid peroxidation activity (nmol of $\mathrm{MDA} \mathrm{mg}^{-1}$ of tissue) in liver and testis of Swiss albino mice in different groups

\begin{tabular}{|c|c|c|c|c|c|}
\hline \multirow[t]{2}{*}{ Experimental groups } & \multicolumn{5}{|c|}{ LPO levels in liver } \\
\hline & Day 1 & Day 3 & Day 7 & Day 14 & Day 30 \\
\hline Adhatoda alone ( $800 \mathrm{mg} \mathrm{kg}^{-1}$ body weight) & $3.11 \pm 0.12$ & $3.42 \pm 0.12$ & $3.41 \pm 0.10$ & $2.30 \pm 0.15^{* *}$ & $2.48 \pm 0.26^{*}$ \\
\hline Radiation (8 Gy) & $6.63 \pm 0.10^{* * *}$ & $11.12 \pm 0.15^{* * *}$ & $14.12 \pm 0.16^{* * *}$ & $12.05 \pm 0.20 * * *$ & No survival \\
\hline Adhatoda + radiation $\left(800 \mathrm{mg} \mathrm{kg}^{-1}\right.$ body weight $\left.+8 \mathrm{~Gy}\right)$ & $5.01 \pm 0.18^{* * *}$ & $6.42 \pm 0.14^{* * *}$ & $7.77 \pm 0.16^{* *}$ & $4.24 \pm 0.12 * * *$ & $5.99 \pm 0.14$ \\
\hline
\end{tabular}

Values are depicted as Mean \pm SD.

Normal (DDW): $3.69 \pm 0.16$

Significance level: $* P<0.05 ; * * P<0.01 ; * * * P<0.001$.

Statistical comparison: Adhatoda versus normal (DDW); radiation versus normal (DDW); Adhatoda + radiation versus radiation.

\section{Modulation of Radiation-Induced Change of Alkaline Phosphatase and Acid Levels in Testis}

Alkaline phosphatase activity showed no significant changes in A. vasica-treated mice as compared to those treated with distilled water except on day 30 there was a significant increase (Table 5). In irradiated group, the alkaline phosphatase activity in testis showed remarkable and significant decline $(P<0.001)$ on all days of observation. In AE-pretreated irradiated mice, a significant recovery in alkaline phosphatase activity was observed. 
Table 4. Change in lipid peroxidation activity (nmol of $\mathrm{MDA} \mathrm{mg}^{-1}$ of tissue) in liver and testis of Swiss albino mice in different groups

\begin{tabular}{|c|c|c|c|c|c|}
\hline \multirow[t]{2}{*}{ Experimental groups } & \multicolumn{5}{|c|}{ LPO levels in testis } \\
\hline & Day 1 & Day 3 & Day 7 & Day 14 & Day 30 \\
\hline Adhatoda alone ( $800 \mathrm{mg} \mathrm{kg}^{-1}$ body weight) & $1.39 \pm 0.15$ & $1.32 \pm 0.14$ & $1.18 \pm 0.10$ & $0.86 \pm 0.10^{*}$ & $0.82 \pm 0.06^{*}$ \\
\hline Radiation (8 Gy) & $6.20 \pm 0.16^{* * *}$ & $9.01 \pm 0.20 * * *$ & $12.12 \pm 0.18 * * *$ & $9.10 \pm 0.12 * * *$ & No survival \\
\hline Adhatoda + radiation $\left(800 \mathrm{mg} \mathrm{kg}^{-1}\right.$ body weight $\left.+8 \mathrm{~Gy}\right)$ & $4.42 \pm 0.10$ & $5.10 \pm 0.18^{* * *}$ & $5.44 \pm 0.16^{* *}$ & $4.08 \pm 0.20^{* * *}$ & $2.46 \pm 0.18$ \\
\hline
\end{tabular}

Values are depicted as Mean \pm SD.

Normal (DDW): $1.65 \pm 0.24$.

Significance level: $* P<0.05 ; * * P<0.01 ; * * * P<0.001$.

Statistical comparison: Adhatoda versus normal (DDW); radiation versus normal (DDW); Adhatoda + radiation versus radiation.

Table 5. Change in alkaline and acid phosphatase activity $\left(\mathrm{mg} \mathrm{pi}^{-1} \mathrm{~h}^{-1}\right)$ in the testis of male Swiss albino mice in different groups

\begin{tabular}{|c|c|c|c|c|c|}
\hline \multirow[t]{2}{*}{ Experimental groups } & \multicolumn{5}{|c|}{ Alkaline phosphatase level } \\
\hline & Day 1 & Day 3 & Day 7 & Day 14 & Day 30 \\
\hline Adhatoda alone ( $800 \mathrm{mg} \mathrm{kg}^{-1}$ body weight $)$ & $5.36 \pm 0.20$ & $5.44 \pm 0.6$ & $5.38 \pm 0.19$ & $5.50 \pm 0.22$ & $6.02 \pm 0.20^{*}$ \\
\hline Radiation (8 Gy) & $2.81 \pm 0.12 * * *$ & $1.88 \pm 0.10^{* * *}$ & $1.59 \pm 0.12^{* * *}$ & $2.24 \pm 0.12 * * *$ & No survival \\
\hline Adhatoda + radiation $\left(800 \mathrm{mg} \mathrm{kg}^{-1}\right.$ body weight $\left.+8 \mathrm{~Gy}\right)$ & $3.46 \pm 0.22 * *$ & $4.36 \pm 0.04 * * *$ & $4.24 \pm 0.29 * * *$ & $4.40 \pm 0.04 * * *$ & $4.34 \pm 0.03$ \\
\hline
\end{tabular}

Values are depicted as Mean \pm SD.

Normal value: $5.40 \pm 0.32$.

Significance level: $* P<0.05 ; * * P<0.01 ; * * * P<0.001$.

Statistical comparison: Adhatoda versus normal (DDW); radiation versus normal (DDW); Adhatoda + radiation versus radiation.

Table 6. Change in alkaline and acid phosphatase activity $\left(\mathrm{mg} \mathrm{pi}^{-1} \mathrm{~h}^{-1}\right)$ in the testis of male Swiss albino mice in different groups

\begin{tabular}{|c|c|c|c|c|c|}
\hline \multirow[t]{2}{*}{ Experimental groups } & \multicolumn{5}{|c|}{ Acid phosphatase level } \\
\hline & Day 1 & Day 3 & Day 7 & Day 14 & Day 30 \\
\hline Adhatoda alone (800 $\mathrm{mg} \mathrm{kg}^{-1}$ body weight) & $3.30 \pm 0.07$ & $3.36 \pm 0.04$ & $3.20 \pm 0.08$ & $3.41 \pm 0.10$ & $3.46 \pm 0.12$ \\
\hline Radiation (8 Gy) & $4.34 \pm 0.03^{* * *}$ & $5.29 \pm 0.12^{* * *}$ & $7.04 \pm 0.10^{* * *}$ & $6.80 \pm 0.04^{* * *}$ & No survival \\
\hline Adhatoda + radiation $\left(800 \mathrm{mg} \mathrm{kg}^{-1}\right.$ body weight $\left.+8 \mathrm{~Gy}\right)$ & $3.34 \pm 0.13^{* * *}$ & $4.81 \pm 0.20 * * *$ & $5.25 \pm 0.08 * * *$ & $3.50 \pm 0.10 * * *$ & $3.75 \pm 0.12$ \\
\hline
\end{tabular}

Values are depicted as Mean $\pm \mathrm{SD}$.

Normal value: $3.41 \pm 0.04$.

Significance level: $* P<0.05 ; * * P<0.01 ; * * * P<0.001$.

Statistical comparison: Adhatoda versus normal (DDW); radiation versus normal (DDW); Adhatoda + radiation versus radiation.

The acid phosphatase activity in testis was found at normal level in A. vasica group as compared to mice treated with distilled water at all autopsy intervals (Table 6). In irradiated group, a highly significant $(P<0.001)$ elevation in the enzyme level was observed. In AE-pretreated irradiated mice, a significant $(P<0.001)$ decline in acid phosphatase activity was observed at all autopsy intervals in comparison to irradiated mice.

\section{Discussion}

Our results confirm the contention of earlier reports (26-30) that irradiation-induced cell death may be a result of accumulation of free radicals, LPO, disruption in the membranes including cellular, nuclear and organelle, leakage of lysosomal acid phosphatases, changes in the surface properties of chromosomes leading to stickiness, breakage of double-strands of DNA and chromosomal aberrations. We were able to clearly document that the extracts of A. vasica significantly restore the glutathione level in the liver, and LPO; acid phosphatase and alkaline phosphatase in testis of mice exposed to irradiation. Furthermore, we observed that the extracts of A. vasica, reduced the stickiness of chromosomes and the chromosomal aberrations induced by radiation. Such a profound effect is observed just after 15 day treatment of A. vasica extract. There is no doubt that the prolonged treatment would yield much improved results. Obviously, the significant increase in increased survival in A. vasica-fed mice could be due to the antioxidant property of A. vasica, as evidenced by restoration of glutathione and LPO levels. Restoration of acid phosphatase level points out the role of the extracts of A. vasica in promoting the stability of cellular, nuclear and organelle membranes. The phytochemical that is responsible for the observed effects of A. vasica is far from clear although the extracts contain several alkaloids such as vasicine, vasicinone and a quinazoline-alkaloid, peganin (31-36). There is a need to test these individual alkaloids for their ability to protect radiation-induced accumulation of free radicals, membrane damage and double-strand 
breakage. Our future goal is to characterize the relative role of these alkaloids in radioprotection.

\section{Acknowledgements}

We thank Dana Ollestad for preparing the photomicrographs and Pooja Selvan for her assistance with the preparation of manuscript.

\section{References}

1. Uma Devi P, Ganasoundari A, Rao BS, Srinivasan KK. In vivo radioprotection by ocimum flavonoids: survival of mice. Radiat Res 1999;151:74-8.

2. Uma Devi P, Ganasoundari A, Vrinda B, Srinivasan KK, Unnikrishnan MK. Radiation protection by ocimum flavonoids orientin and vicenin: mechanism of action. Radiat Res 2000;154:455-60.

3. Lamartiniere CA, Cotroneo MS, Fritz WA, Wang J, Mentor-Marcel R, Elgavish A. Genistein chemoprevention: timing and mechanisms of action in murine mammary and prostate. $J$ Nutr 2002;132:552S-8S.

4. Castillo J, Benavente-Garcia O, Lorente J, Alcaraz M, Redondo A, Ortuno A, et al. Antioxidant activity and radioprotective effects against chromosomal damage induced by X-rays of flavan-3-ols (procyanidins) from grape seeds (Vitis vinifera): comparative study versus other phenolic and organic compounds. J Agric Food Chem 2000;48:1738-45.

5. Jagetia GC, Venkatesh P, Baliga MS. Evaluation of the radioprotective effect of $A$. vasica leaf (A. vasicagle marmelos) extract in mice. Int $J$ Radiat Biol 2004;80:281-90.

6. Kumar A, Verma S, Kumar M, Kiefer J. Radio-modifying effects of Spirulina. 1st International Congress on Traditional Medicine and Materia Medica, Tehran, 2000, 34.

7. Samarth RM, Kumar A. Mentha piperita (Linn.) leaf extract provides protection against radiation induced chromosomal damage in bone marrow of mice. Indian J Exp Biol 2003;41:229-37.

8. Kumar A, Qiblawi S, Khan A, Banerjee S, Rao AR. Chemomodulatory action of Brassica compestris (Var Sarason) on hepatic carcinogen metabolizing enzyme, antioxidant profiles and lipid peroxidation. Asia Pacific J Cancer Prev 2004;5:190-5.

9. Krishna A, Kumar A. Evaluation of radioprotective effects of Rajgira (Amaranthus paniculatus) extract in Swiss albino mice. J Radiat Res (Tokyo) 2005;46:233-9.

10. Padmavathi B, Rath PC, Rao AR, Singh RP. Roots of Withania somnifera inhibit forestomach and skin carcinogenesis in mice. Evid Based Complement Altern Med 2005;2:99-105.

11. Han Y, Son S-J, Akhalaia M, Platonov A, Son H-J, Lee K-H, et al. Modulation of radiation-induced disturbances of antioxidant defense systems by ginsan. Evid Based Complement Altern Med 2005;2:529-36.

12. Kumar A, Ram J, Samarth RM, Kumar M. Modulatory influence of Adhatoda vasica Nees leaf extract against gamma irradiation in Swiss albino mice. Phytomedicine 2005;12:285-93.

13. Sharma ML, Atal CK. Oxytocic, thrombopoietic and broncho-dilatory activities of Vasicine-A novel molecule isolated form Adhatoda vasica Nees. In: Sairam TV (ed). Home Remedies. Vol. II. Penguin, New Delhi, 1999.

14. Amin AH, Mehta DR. A bronchodilator alkaloid (vasicinone) from Adhatoda vasica Nees. Nature 1959;184(Suppl 17):1317.

15. Dorsch W, Wagner H. New antiasthmatic drugs from traditional medicine? Int Arch Allergy App Immunol 1991;94:262-5.
16. Paliwa JK, Dwivedi AK, Singh S, Gutpa RC. Pharmacokinetics and in-situ absorption studies of a new anti-allergic compound 73/602 in rats. Int $J$ Pharm 2000;197:213-20.

17. Grange JM, Snell NJ. Activity of bromohexine and ambroxiol, semisynthetic derivatives of vaccine from the Indian shrub Adhatoda vasica, against Mycobacterium tuberculosis in vitro. J Ethno Pharmacol 1996;50: 49-53.

18. Barry VC, Conalty ML, Rylance HJ, Smith FR. Antitubercular effect of an extract of Adhatoda vasica. Nature 1955;176:119-20.

19. Gupta KC, Chopra IC. Anti-tubercular action of Adhatoda vasica (N.O. acanthacea). Indian J Med Res 1954;42:355-8.

20. Singh RP, Padmavathi B, Rao AR. Modulatory influence of Adhatoda vesica (Justicia adhatoda) leaf extract on the enzymes of xenobiotic metabolism, antioxidant status and lipid peroxidation in mice. Mol Cell Biochem 2000;213:99-109.

21. Savage JR. Classification and relationships of induced chromosomal structural changes. J Med Genet 1976;12:103-22.

22. Moron MS, Depierre JW, Mannervik B. Levels of glutathione, glutathione reductase and glutathione $S$-transferase activities in rat lungs and liver. Biochim Biophys Acta 1979;582:67-78.

23. Ohkawa H, Ohishi N, Yagi K. Assay for lipid peroxidation in mouse tissue by thiobarbituric acid reaction. Anal Biochem 1979;95:351-8.

24. Fiske $\mathrm{CH}$, Subbarow Y. The colorimetric determination of phosphorus J Biochem 1925;66:375-400.

25. Bourke GJ, Daly LE, McGilvary JC. Interpretation and Uses of Medical Statistics, 3rd edition. Oxford: Blackwell Scientific Publications, 1985

26. Casarett AP. Radiation Biology. Englewood Cliffs, NJ, USA: Prentice Hall Inc., 1968.

27. Natarajan AT, Obe G, Van Zeeland AA, Palitti F, Meijers F, VerdegaalImmerzeel EA. Molecular mechanisms involved in production of chromosome aberrations. II. Utilization of Neurospora endonuclease for the study of aberration production by X-rays in G1 and G2 stages of cell cycle. Mutat Res 1980;69:293-305.

28. Bryant PE. Use of restriction endonuclease to study relationship between DNA double-strand breaks, chromosomal aberrations and other end point in mammalian cells. Int J Radiat Biol 1988;54:869-90.

29. DeLeve LD, Wand X, Kuhlenkamp JF, Kaplowitz N. Toxicity of azathioprine and monocrotaline in murine sinusoidal endothelial cells and hepatocytes: the role of glutathione and relevance to hepatic venoocclusive disease. Hepatology 1996;23:589-99.

30. McCoy RN, Hill KE, Ayon MA, Stein JH, Burk RF. Oxidative stress following renal ischemia, changes in the glutathione redox ratio. Kidney Int 1988;33:812-7.

31. Gupta OP, Sharma ML, Ghatak BJ, Atal CK. Pharmacological investigations of vasicine and vasicinone-the alkaloids of Adhatoda vasica. Indian J Med Res 1977;66:680-91.

32. Gupta OP, Anand KK, Ghatak BJ, Atal CK. Vasicine, alkaloid of Adhatoda vasica, a promising uterotonic abortifacient. Indian J Exp Biol 1978;16:1075-7.

33. Johne S, Waiblinger K, Groger D. Studies on biosynthesis of the quinazoline alkaloid peganin in Adhatoda vasica Nees. Pharmazie 1973;28:403-6.

34. Johne S, Groger D, Richter G. On the biosynthesis of peganine in Adhatoda vasica Nees. Arch Pharm Ber Dtsch Pharm Ges 1968;301: 721-7.

35. Das C, Poi R, Chowdhury A. HPTLC determination of vasicine and vasicinone in Adhatoda vasica. Phytochem Anal 2005;16:90-2.

36. Pahwa GS, Zutshi U, Atal CK. Chronic toxicity studies with vasicine from Adhatoda vasica Nees in rats and monkeys. Indian J Exp Biol 1987;25: 467-70. 


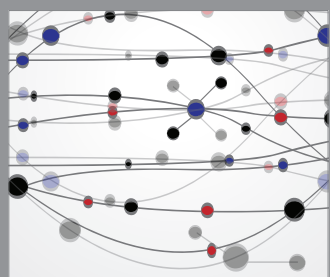

The Scientific World Journal
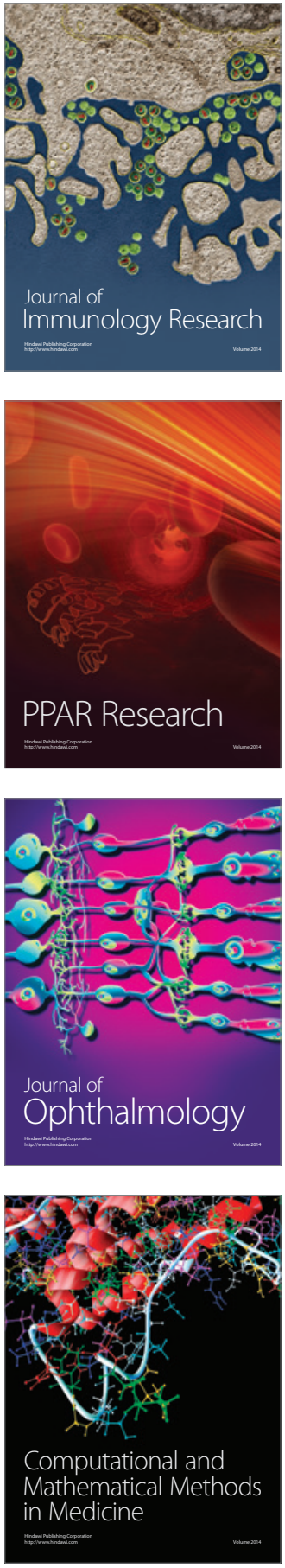

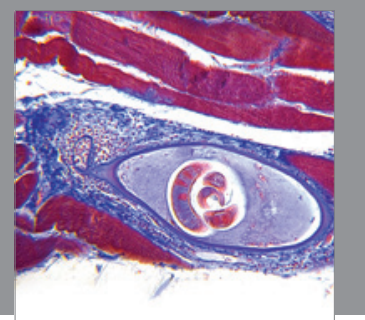

Gastroenterology

Research and Practice
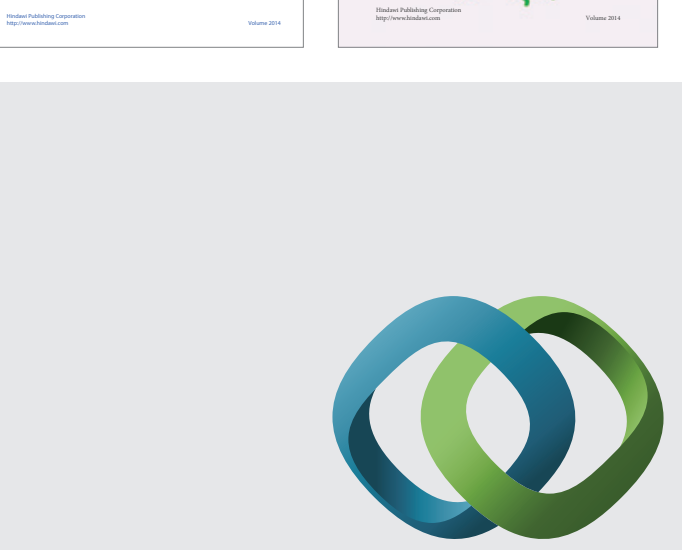

\section{Hindawi}

Submit your manuscripts at

http://www.hindawi.com
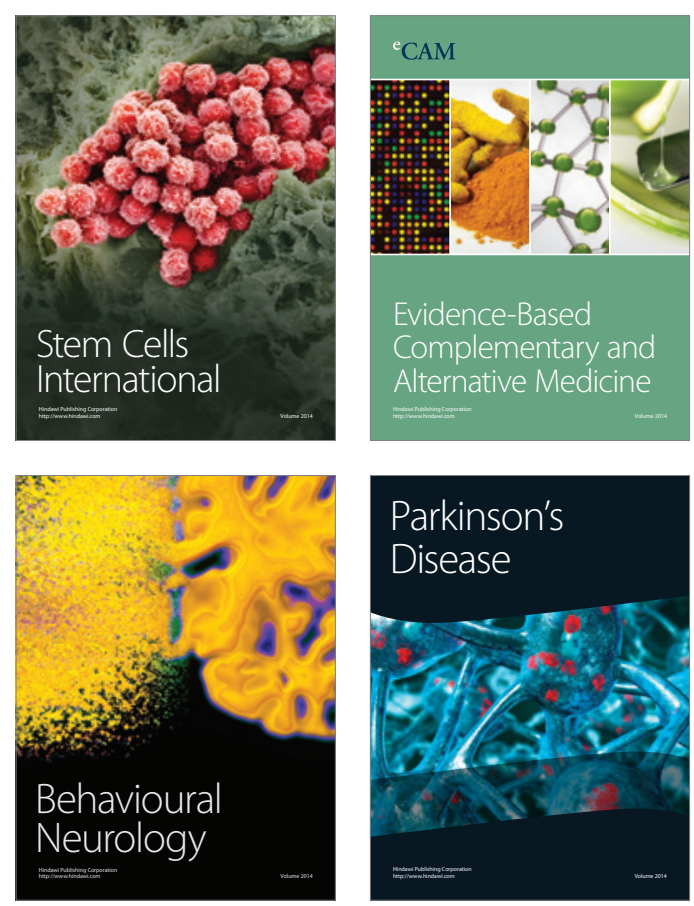

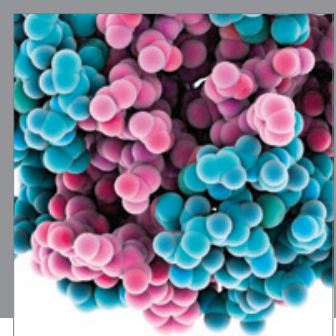

Journal of
Diabetes Research

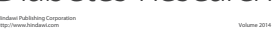

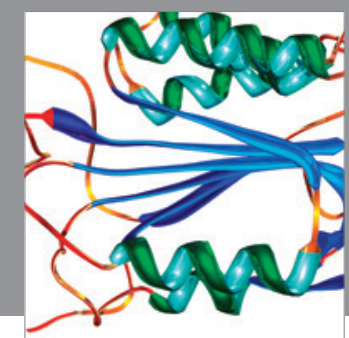

Disease Markers
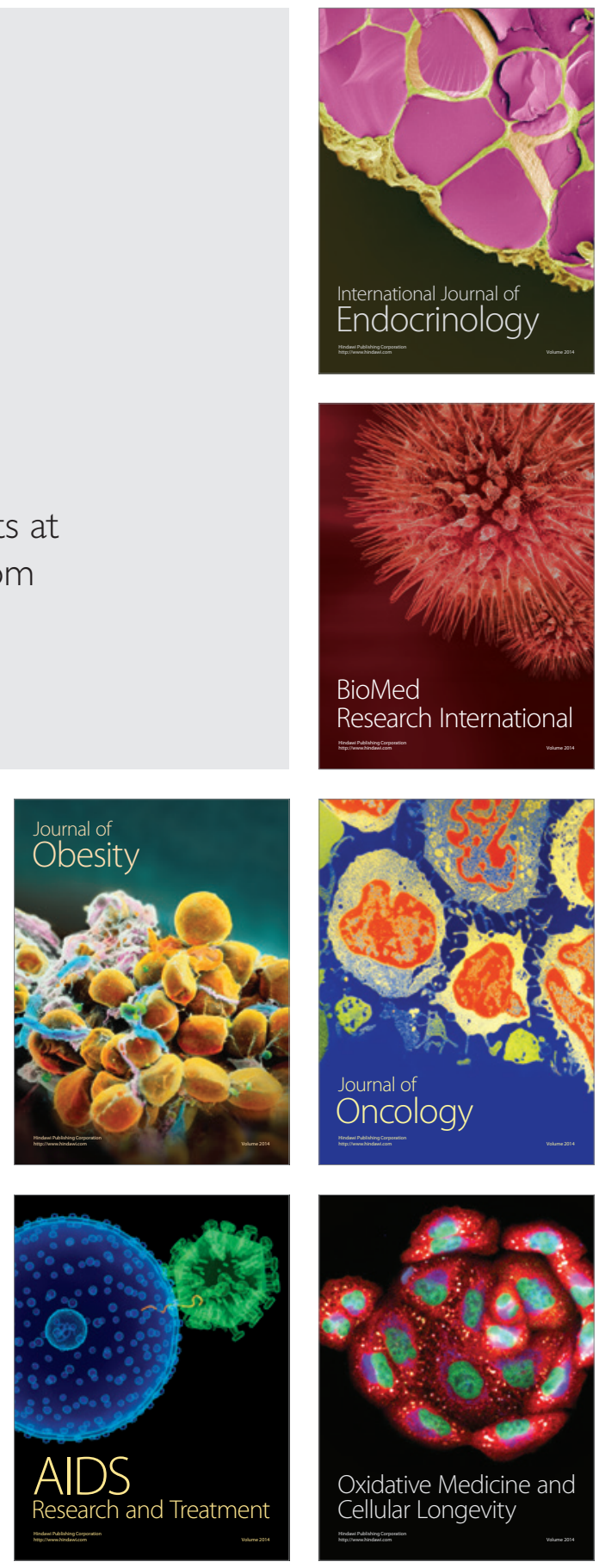